\title{
Pengembangan Perangkat Pembelajaran Matematika Berorientasi Konstruktivisme untuk Siswa SMK Kompetensi Keahlian Teknik Komputer dan Jaringan
}

\author{
Dwi Astuti $^{1} *$, Heri Retnawati ${ }^{2}$ \\ ${ }^{1}$ Universitas Negeri Yogyakarta. Jl. Colombo No. 1 Karangmalang, Yogyakarta, Indonesia. \\ ${ }^{2}$ Universitas Negeri Yogyakarta. Jl. Colombo No. 1 Karangmalang, Yogyakarta, Indonesia. \\ * Korespondensi Penulis. E-mail: dwi.astuti.06@gmail.com \\ Received:10 January 2017; Revised:10 March 2017; Accepted: 10 April 2017
}

\begin{abstract}
Abstrak
Penelitian ini bertujuan untuk menghasilkan perangkat pembelajaran berorientasi konstruktivisme, meliputi Rencana Pelaksanaan Pembelajaran (RPP), Lembar Kegiatan Siswa (LKS), dan Tes Hasil Belajar (THB) mata pelajaran matematika SMK kompetensi keahlian Teknik komputer dan Jaringan (TKJ) yang valid, praktis, dan efektif. Penelitian ini merupakan penelitian pengembangan model 4D yang terdiri atas empat tahap, yaitu: (1) defining (pendefinisian); (2) designing (perancangan); (3) developing (pengembangan); (4) disseminating (diseminasi). Subjek uji coba penelitian yaitu 56 peserta didik SMK Muhamamdiyah 2 Yogyakarta dan seorang guru matematika SMK Muhammadiyah 2 Yogyakarta. Data kevalidan dan kepraktisan dikonversikan dari data kuantitatif menjadi data kualitatif dengan menggunakan tabel kriteria. Data keefektifan dianalisis dengan menggunakan uji one sample t-test. Untuk menguji kelebihefektifan perangkat pembelajaran berorientasi konstruktivisme daripada perangkat pembelajaran konvensional, data dianalisis dengan menggunakan MANOVA yang kemudian dilanjutkan dengan uji $t$-Benferroni. Hasil validasi menunjukkan bahwa perangkat pembelajaran valid. Perangkat pembelajaran telah memenuhi kriteria praktis. Hasil pengujian keefektifan menunjukkan bahwa perangkat pembelajaran berorientasi konstruktivisme lebih efektif daripada perangkat pembelajaran konvensional untuk materi peluang ditinjau dari aspek hasil belajar dan kepercayaan diri peserta didik.
\end{abstract}

Kata Kunci: pengembangan, perangkat pembelajaran, konstruktivisme, kepercayaan diri

\section{Developing A Constructivism Learning Kit of Mathematics for Vocational Students in Computer and Networks Engineering Competency}

\begin{abstract}
This research aimed to develop a Constructivist Learning Kit of Mathematics, consisting of valid, practical, and effective lesson plans, worksheets, and learning achievement tests (THB) The research was a 4D development research that consisted of four phases: (1) defining, (2) designing, (3) developing, (4) disseminating. The subjects of the research were 56 students of SMK Muhammadiyah 2 Yogyakarta and a mathematics teacher of SMK Muhammadiyah 2 Yogyakarta. The data of validity and practicality of the results converted from quantitative data to qualitative data using the guideline criteria. To test the effectiveness of the learning, the data were analyzed using a one sample t-test. To test the effectiveness of the learning-oriented excess of constructivism than conventional learning kit, the data were analyzed using MANOVA followed by t-test Benferroni. The products were valid and practical. The test results showed that constructivism learning kit was more effective than conventional learning kit for probability material in terms learning achievement and self-confidence aspects.
\end{abstract}

Keywords: development, learning kit, constructivism, self-confidence

How to Cite: Astuti, D., \& Retnawati, H. (2017). Pengembangan perangkat pembelajaran matematika berorientasi konstruktivisme untuk siswa SMK kompetensi keahlian teknik komputer dan jaringan. Jurnal Pendidikan Matematika dan Sains, 5(1). doi:http://dx.doi.org/10.21831/jpms.v5i1.13482

Permalink/DOI: DOI: http://dx.doi.org/10.21831/jpms.v5i1.13482 


\section{PENDAHULUAN}

Pendidikan memiliki peranan penting dalam peningkatan kualitas sumber daya manusia, agar mampu bersaing di era globalisasi ini. Tujuan pendidikan yang dinyatakan dalam Undang-Undang No. 20 Tahun 2003 tentang Sistem Pendidikan Nasional bahwa pendidikan nasional bertujuan untuk mengembangkan poten-si peserta didik agar menjadi manusia yang berilmu, cakap, kreatif, mandiri, dan menjadi warga negara yang demokratis serta bertanggung jawab. Merujuk pada tujuan pendidikan nasional tersebut, hasil pembelajaran yang berlangsung diharapkan dapat mengarahkan peserta didik yang mempunyai kemampuan sesuai dengan kompetensi mata pelajaran yang dipelajari dan kemampuan untuk meningkatkan potensi yang dimiliki.

Secara spesifik luaran yang ingin dicapai melalui pendidikan di Indonesia dituangkan dalam Permendikbud No. 54 Tahun 2013 yang menyebutkan bahwa untuk mewujudkan tujuan pendidikan nasional tersebut diperlukan profil kualifikasi kemampuan lulusan yang dituangkan dalam Standar Kompetensi Lulusan (SKL). SKL adalah kriteria mengenai kualifikasi kemampuan lulusan yang mencakup sikap, pengetahuan, dan keterampilan. SKL ini akan dirinci pada kompetensi inti dan kompetensi dasar yang akan dijabarkan pada indikator ketercapaian kompetensi dasar. Hal ini pun mengindikasikan bahwa tercapainya indikator ketercapaian kompetensi dasar merupakan hal yang sangat penting untuk bisa menentukan kelulusan siswa dalam mata pelajaran tertentu, termasuk mata pelajaran matematika untuk suatu materi tertentu.

Tercapainya indikator ketercapaian kompetensi dasar berhubungan dengan hasil belajar matematika peserta didik. Mengenai pentingnya hasil belajar matematika, Lovat, et al. (2011, p.6) mengungkapkan bahwa "since the early 1990s, there has been a concentration of effort aimed at maximizing student achievement in school edu-cation." Bahwa sejak tahun 1990-an, konsentrasi pembelajaran di sekolah adalah memaksimalkan hasil belajar peserta didik.Akan tetapi, harapan ini tidaklah sejalan dengan fakta yang terjadi. Dehyadegary, et al, (2012, p.823) mengung-kapkan bahwa "one of the vast crises of the educational system in many countries, especially third world countries is the problem of low academic achievement." Salah satu krisis terbes-ar sistem pendidikan di banyak negara, khusus-nya negara berkembang adalah masalah rendah-nya prestasi akademik atau hasil belajar peserta didik. Indonesia menjadi salah satu negara ber-kembang dan hal tersebut pun sejalan dengan fakta yang terjadi di Indonesia. Data BSNP mengenai laporan hasil ujian nasional (UN) matematika SMK kelompok teknik di Kota Yogyakarta untuk materi peluang pada tahun pelajaran 2010/2011 menunjukkan bahwa daya serapnya mencapai 55,94 dan tahun pelajaran 2011/2012 daya serap mencapai 58,38. Selama dua tahun berturut-turut daya serap untuk materi peluang masih rendah. Hal ini disinyalir disebabkan oleh beberapa faktor.

Salah satu faktor penyebab rendahnya ketercapaian kompetensi yang ditunjukkan di atas yaitu penguasaan konsep oleh peserta didik yang masih rendah. Banyak peserta didik yang mengalami kebingungan mana permasalahan yang dapat diselesaikan dengan permutasi dan mana yang harus diselesaikan dengan konsep kombinasi. Pembelajaran yang cenderung satu arah dari mengakibatkan penanaman konsep yang kurang kuat. Jika menemukan masalah yang berbeda peserta didik akan mengalami kebi-ngungan. Hal ini menunjukkan kesenjangan antara harapan dan fakta yang terjadi di lapangan.

Melihat fakta yang belum sesuai dengan harapan tersebut, sebagai pendidik tentu harus melakukan upaya-upaya untuk memperbaiki sistem pembelajaran matematika di Indonesia yang masih belum optimal. Padahal selain permasalahan pada ranah kognitif seperti yang telah dipaparkan tersebut, juga perlu diperhatikan permasalahan-permasalah lain dari segi psikis atau afektif.

Salah satu kompetensi pada ranah efektif yang penting dimiliki siswa yaitu berkaitan dengan self-confidence atau rasa percaya diri. Kloosterman mengungkapkan bahwa selfconfidence sangat penting bagi peserta didik agar berhasil dalam belajar matematika (Yates, 2002 , p.5). Hal ini didukung oleh beberapa studi terdahulu mengungkapkan adanya hubungan antara self-confidence dengan hasil belajar. Hannula, et al. (2004, p.17) mengungkapkan bahwa hasil belajar matematika dipengaruhi oleh keyakinan terhadap matematika, khususnya oleh rasa percaya diri dalam matematika. Dalam Permendikbud No. 54 Tahun 2013 juga disebut-kan bahwa salah satu kompetensi lulusan untuk ranah afektif peserta 
didik yaitu peserta didik memiliki rasa percaya diri dalam kehidupannya.

Berkaitan dengan kepercayaan diri, Nunes, et al. (2009, p.24) berpendapat bahwa "one can form a measure of children's selfconfidence by considering their answers about how much they like maths and also how good they think they are in the subject". Artinya adalah kepercayaan diri peserta didik terhadap matematika dapat diukur dengan pertanyaan yang berkaitan dengan sebe-rapa besar mereka menyukai matematika dan seberapa bagus kemampuan mereka dalam matematika menurut persepsi mereka sendiri (konsep diri terhadap matematika).

Selain itu tedapat beberapa aspek lain yang juga berpengaruh terhadap pembentukan keper-cayaan diri. Preston (2007, p.14) mengung-kapkan ada 5 aspek pembangun kepercayaan diri yaitu: kesadaran diri, niat (intention), berpikir positif dan rasional, berpikir kreatif pada saat bertindak, serta bertindak. Hal senada juga diung-kapkan Lauster (Ghufron \& Risnawati, 2012, pp.35-36), bahwa aspek-aspek kepercayaan diri meliputi: keyakinan terhadap kemampuan diri sendiri, optimis, objektif, bertanggung jawab, serta rasional dan realistis. Lie (2003, p.4) mengungkapkan bahwa ciri-ciri orang yang memiliki rasa percaya diri adalah: (1) yakin kepa-da diri sendiri; (2) mandiri; (3) tidak ragu-ragu; (4) merasa diri berharga; (5) tidak menyom-bongkan diri; dan (6) memiliki keberanian untuk bertindak. Terkait dengan matematika, Margono (2005, pp.48-49) mengungkapkan bahwa keper-cayaan diri peserta didik dalam matematika dapat dibagi dalam tiga aspek yaitu: (1) kepercayaan terhadap pemahaman dan kesadaran diri terhadap kemampuan matematikanya, (2) kemampuan untuk menentukan secara realistik sasaran yang ingin dicapai dan menyusun rencana aksi sebagai usaha meraih sasaran, serta (3) kepercayaan terhadap matematika itu sendiri. Sedangkan menurut Lindenfield (1997, p.15-16) untuk mengembangkan rasa percaya diri, seseorang perlu mengalami dan bereksperimen dengan beraneka ragam hubungan, dari yang dekat dan akrab di rumah sampai ke yang lebih asing. Untuk itu, guru perlu menciptakan suasana belajar yang dapat memfasilitasi peserta didik untuk lebih leluasa dan tidak canggung dalam berinteraksi dengan teman maupun gurunya.

Merujuk pada beberapa ahli tersebut rasa percaya diri peserta didik terhadap matematika ialah keyakinan peserta didik terhadap kemampuannya dalam belajar maupun menghadapi masalah-masalah matematika. Adapun aspekaspek kepercayaan diri peserta didik terhadap matematika, diantaranya adalah: (1) keyakinan terhadap kemampuan matematisnya; (2) ketegasan; (3) berpikir realistik dan rasional; dan (4) berpikir positif. Aspek-aspek tersebutlah yang diperlukan oleh peserta didik selama proses pembelajaran matematika dan guna mendukung prestasi belajar mereka.

Gambaran mengenai kondisi ideal tekait pentingnya rasa percaya diri peserta didik dalam pembelajaran matematika kontradiksi dengan fakta yang terjadi di lapangan. Berdasarkan observasi yang dilakukan peneliti pada pembelajaran matematika di kelas XI SMK TKJ di Kota Yogyakarta terlihat bahwa pada saat pembelajaran, peserta didik masih mempunyai rasa kepercayaan diri yang cenderung rendah. Mereka masih takut untuk menyatakan pendapatnya di kelas. Hal tersebut mengindikasikan rendahnya kepercayaan diri peserta didik karena hal tersebut merupakan bagian dari indikator kepercayaan diri. Oleh sebab itu jika menghadapi suatu masalah, peserta didik dengan rasa kepercayaan diri rendah biasanya enggan untuk berusaha menemukan solusi dan memilih untuk menunggu saja jawaban yang akan diberikan guru atau melihat jawaban milik teman yang lain. Hal ini perlu mendapat perhatian khusus dari para guru. Sebab gurulah yang memegang peran utama dalam memfasilitasi peserta didik agar mampu memiliki rasa percaya diri yang tinggi dalam belajar matematika. Guru harus mampu mengubah pandangan peserta didik tentang mata pelajaran matematika yang dianggap sulit dan tidak dekat dengan dunia mereka menjadi matematika yang menyenangkan dan penuh makna, sehingga tujuan pembelajaran dapat tercapai.

Guna mencapai tujuan pembelajaran, selama proses pembelajaran guru mempunyai peran sentral yaitu sebagai perencana, pelaksana, dan evaluator. Untuk melaksanakan peran terse-but, guru harus memberikan keteladanan, mem-bangun kemauan, mengembangkan potensi dan kreativitas peserta didik. Kemauan membangun dan mengembangkan potensi peserta didik dapat dilakukan dengan memfasilitasi dan memberikan arahan kepada peserta didik. Peran guru sebgai fasilitator adalah memberikan kesempatan kepa-da peserta didik untuk berkembang sesuai dengan potensinya. 
Untuk mengorganisasikan pelaksanaan pembelajaran agar berlangsung dengan baik diperlukan suatu perencanaan. Perencanaan akan mempermudah dalam menentukan target ketercapaian sebelum pelaksanaan dilakukan, menentukan langkah-langkah yang harus dijalankan selama pelaksanaan, dan mempermudah dalam evaluasi setelah proses pelaksanaan (Harjanto, 2003, pp.17-19). Berkaitan dengan pentingnya perencanaan, Orlich, et al. (2007, p.64) menyatakan bahwa "One hallmark of teaching as an organized activity is the process of planning". Bagian penting dari pembelajaran sebagai pengorganisasian aktivitas peserta didik adalah proses perencanaan. Apa yang akan dilakukan seorang guru untuk mengorganisasi kegiatan peserta didik harus direncakan dengan tepat. Sejalan dengan hal tersebut Jacobsen, Eggen, \& Kauchak (1989, p.106) memperkuat bahwa"The most important value in learning to plan lessons is that it provides a way to help teachers learn to think about what they are doing. A second important reason for planning is emotional'.Dari pernya-taan tersebut dijelaskan bahwa nilai penting dari sebuah perencanaan pembelajaran adalah untuk membantu guru dalam merencanakan apa yang akan mereka lakukan saat pembelajaran berlang-sung. Selain itu, seorang guru harus dapat mem-persiapkan emosionalnya saat pembelajaran ber-langsung. Hal ini bertujuan agar saat pembe-lajaran guru bisa melakukan tugasnya secara totalitas.

Terkait regulasi pemerintah melalui Peraturan Menteri Pendidikan dan Kebudayaan (Permendikbud) No. 65 Tahun 2013 disebutkan bahwa perencanaan pembelajaran dirancang dalam bentuk silabus dan Rencana Pelaksanaan Pembelajaran (RPP) yang mengacu pada standar isi. Dalam RPP minimal memuat identitas sekolah, identitas mata pelajaran, alokasi waktu, tujuan pembelajaran, kompetensi dasar dan indikator pencapaian kompetensi, materi pembelajaran, metode pembelajaran, media pembelajaran, sumber belajar, langkah-langkah pembelajaran, dan penilaian hasil pembelajaran. Dinya-takan juga bahwa setiap pendidik pada satuan pendidikan berkewajiban menyusun RPP secara lengkap dan sistematis agar pembelajaran ber-langsung secara interaktif, inspiratif, menyenangkan, menantang, efisien, memotivasi peserta didik untuk berpartisipasi aktif, serta memberi-kan ruang yang cukup bagi prakarsa, kreativitas, dan kemandirian sesuai dengan bakat, minat, dan perkembangan fisik serta psikologis peserta didik.
Berkaitan dengan rencana pelaksanaan pembelajaran Stringer, Christensen, dan Baldwin (2010, p.4) menyebutkan bahwa

Planning a lesson is more than just setting out a program of learning, however. A teacher must take into account not only the information or skills to be learned, but also the characteristics and capabilities of the students in the class. A successful program of learning requires careful alignment of what is to be learned with the qualities of the learner.

Hal tersebut menjelaskan bahwa membuat rencana pelaksanaan pembelajaran lebih dari sekedar menyusun suatu program pembelajaran, seorang guru harus tidak hanya menentukan sejumlah informasi atau keterampilan yang dipelajari, tetapi juga karakteristik dan kapabilitas peserta didik dalam kelas.

Selain silabus dan RPP, perangkat lain yang perlu direncanakan yaitu LKS yang berfungsi sebagai media atau sumber belajar untuk memfasilitasi pembelajaran sesuai dengan kegiatan pembelajaran yang dikembangkan. LKS merupakan media atau sumber belajar yang dapat digunakan untuk mengubah paradigma pembe-lajaran yang berpusat pada guru (teacher centered) menjadi berpusat pada peserta didik (student centered). Keuntungan adanya LKS yaitu akan memudahkan guru dalam melaksanakan pembelajaran dan peserta didik akan belajar secara mandiri. Dengan demikian peranan perangkat pembelajaran seperti RPP dan LKS sangat penting dalam menunjang ketercapaian tujuan pembelajaran.

Sementara itu dari hasil prasurvei menunjukkan bahwa di penyusunan perangkat pembelajaran oleh beberapa guru matematika di Kota Yogyakarta masih kurang optimal. Sebagian guru masih meng-copy file dari teman atau dari hasil download. Hal tersebut dilakukan karena guru merasa kurang memiliki waktu yang longgar jika harus menyusun perangkat pembelajaran sesuai norma dalam Permendikbud. Karena hanya meng-copy file dari teman atau dari hasil download, maka perangkat yang disusun akan monoton tanpa memperhatikan karakter peserta didik, karakter materi dan kesesuaian metode pembelajaran. Kurikulum 2013 mengamanahkan perangkat pembelajaran yang berbeda dari KTSP sehingga dibutuhkan contoh perangkat pembe-lajaran untuk Kurikulum 2013. Padahal keter-sediaan contoh perangkat pembelajaran yang mengimplementasikan Kurikulum 2013 dan 
memberikan ruang agar peserta didik untuk aktif membangun pengetahuannya masih terbatas. Dengan kata lain prinsip pembelajaran konstruktivisme belum dapat diterapkan dengan baik oleh guru.

Salah satu kata kunci dalam keberhasilan yaitu peran aktif siswa. Pembelajaran yang melibatkan peran aktif siswa (seperti saintifik, PMRI, dan inkuiri) efektif dan dapat meingkatkan percaya diri dan prestasi belajar peserta didik (Hilman \& Retnawati, 2015; Mundilarto, 2013; Suhendar \& Widjajanti, 2016). Pada prinsipnya pembelajaran saintifik, PMRI, dan inkuiri memiliki kesamaan, yaitu menganut paradigma pembelajaran konstruktivisme. Pem-belajaran konstruktivisme merupakan model pembelajaran yang disesuaikan dengan situasi dan kondisi peserta didik, karakter dari setiap indikator, dan kompetensi yang hendak dicapai pada setiap indikator. Pendekatan konstruk-tivisme memberikan peluang kepada peserta didik untuk mengkonstruksi pengetahuan dan pemahaman mereka melalui pengalaman dan pemikiran tentang pengalamannya (Matthews, 2003, p.60). Berkaitan dengan konstruktivisme, Piaget (1971, pp.77-78) berpendapat bahwa belajar dibangun dari masing-masing penga-laman individu dan hubungan antara konsep yang dipelajari sebelumnya dengan ide-ide baru. Hal tersebut mengarah ke ide disequilibrium, yang mendorong proses pembelajaran. Teori disequilibrium Piaget menjelaskan kapan ide-ide baru dan konsep tidak sesuai dengan apa yang diketahui seseorang. Oleh karena itu, seseorang dipaksa untuk menyesuaikan pemikiran seseorang tersebut untuk menggabungkan informasi baru ini. Konsepsi Piaget dari equilibrium menyiratkan proses konstruksi dinamis dari struktur kognitif manusia. Jadi, Piaget menjelaskan bahwa penkonstruksian pengetahuan dilakukan sendiri oleh peserta didik atau dengan kata lain pengkonstruksian secara individu.

Berkaitan dengan tahap perkembangan kognitif, Piaget menjelaskan bahwa ada 4 tahap perkembangan kognitif seorang anak yaitu (Slavin, 2006, p.33-39): yaitu tahap sensori motor (0-2 tahun) seorang anak akan belajar untuk menggunakan dan mengatur kegiatan fisik dan mental menjadi rangkaian perbuatan yang bermakna. Tahap pra-operasional (2-7 tahun), seorang anak ]belum mampu untuk melihat hubungan-hubungan dan menyimpulkan sesuatu secara konsisten. Tahap operasional konkret (711 tahun), seorang anak dapat membuat kesimpulan dari suatu situasi nyata atau dengan menggunakan benda konkret, dan mampu mempertimbangkan dua aspek dari suatu situasi nyata secara bersama-sama (misalnya, antara bentuk dan ukuran). Tahap operasional formal (lebih dari 11 tahun), kegiatan kognitif seseorang tidak mesti menggunakan benda nyata.

Berkaitan dengan pembelajaran konstruktivisme, Vygotsky mengemukakan tiga prinsip yaitu (1) socially meaningful activity (Aktivitas sosial yang bermakna). Vygotsky menyatakan bahwa peserta didik belajar melalui interaksi bersama dengan orang dewasa atau teman yang lebih cakap. (Vygotsky, 1986, p.xxiii-xxiv); (2) ZPD (zone of proximal development). Bahwa peserta didik akan dapat mempelajari konsepkonsep dengan baik jika berada dalam ZPD. Peserta didik bekerja dalam ZPD jika peserta didik tidak dapat memecahkan masalah sendiri, tetapi dapat memecahkan masalah itu setelah mendapat bantuan orang dewasa atau temannya (peer). ZPD menitikberatkan pada interaksi sosial akan dapat memudahkan perkembangan anak. (Vygotsky, 1986, p.xxxv); (3) mediated learning (pembelajaran termediasi). Vygostky menekankan pada scaffolding. Scaffolding merupakan suatu istilah pada proses yang digunakan orang dewasa untuk menuntun anak-anak melalui ZPD-nya. Peserta didik diberi masalah yang kompleks, sulit, dan realistik, dan kemudian diberi bantuan secukupnya dalam memecah-kannya (Vygotsky, 1986, p.xxxv).

Vygotsky menekankan pentingnya memanfaatkan lingkungan dalam pembelajaran. Lingkungan sekitar peserta didik meliputi orangorang, kebudayaan, termasuk pengalaman dalam lingkungan tersebut. Orang lain merupakan bagian dari lingkungan, pemerolehan pengetahuan peserta didik bermula dari lingkup sosial, antarorang, dan kemudian pada lingkup individu sebagai peristiwa internalisasi. Dalam perkembangannya, konstruktivisme memang banyak digunakan dalam pembelajaran. Berkaitan dengan prinsip pengkonstruksian pengetahuan selama proses pembelajaran yang mengacu pada teori-teori konstruktivisme. Menurut Karagiogi dan Symeou (2005, p.24) bahwa pembelajaran merupakan pendekatan sebagai konstruksi, regulasi diri, situasi, kooperatif, dan proses individual yang berbeda. Konstruktivisme bisa dikatakan sebagai teori penemuan dan teori tentang perkembangan kognitif seseorang. Selain itu konstruktivisme juga bisa dipandang sebagai teori pembelajaran yang diaplikasikan 
untuk mencapai beberapa tujuan pembelajaran yang akan dicapai.

Beberapa prinsip pembelajaran konstruktivisme yang dinyatakan oleh Clements dan Battista (2009, pp.6-7) yaitu (1) "Knowledge is actively created or invented by the child, not passively received from the environment." Pernyataan tersebut berarti bahwa pengetahuan itu secara aktif dibangun atau ditemukan oleh anak; (2) "Children create new mathematical knowledge by reflecting on their physical and mental actions." Anak akan membangun pengetahuan matematika yang baru dengan merefleksikan dalam kegiatan fisik dan mental; (3) "No one true reality exists, only individual interpretations of the world." Tidak ada kebenaran yang mutlak di dunia ini, yang ada hanyalah interpretasi dari manusia saja. Hal ini menunjukkan bahwa segala sesuatu yang ada di dunia ini hanya relatif sesuai ruang dan waktu.; (4) "Learning is a social process in which children grow into the intellectual life of those around them." Pembelajaran merupakan proses social dimana anak-anak akan tumbuh kehidupan intelektualnya dalam lingkungan mereka.

Beberapa ahli mengemukakan beberapa model pembelajaran konstruktivisme diantaranya model siklus belajar dan model Gagnon dan Collay. Karplus and Thier for SCIS, the Science Curriculum Improvement Study (Brown \& Abell, 2007, p.58), menyebutkan bahwa model siklus terdiri atas tiga langkah yaitu: (1) eksplorasi; di dalamnya, guru mendorong para peserta didik untuk menghasilkan pertanyaan dan melakukan penyelidikan. (2) Pengenalan konsep; peserta didik akan membangun pengetahuan mereka melalui interaksi yang dilakukan dengan teman sebaya, buku, ataupun dengan gurunya. (3) Aplikasi konsep; peserta didik bekerja pada permasalahan baru yang mempertimbangkan kembali konsep belajar yang dikaji dalam tahap satu dan dua.

Sedangkan model konstruktivisme Gagnon dan Collay terdiri atas enam tahapan, yakni: (1) situasi; situasi diuraikan atau digambarkan dalam suatu proses memecahkan permasalahan, menjawab pertanyaan, membuat keputusan, menggambar, membuat kesimpulan, atau menen-tukan tujuan. (2) Pengelompokan; pengelom-pokan ini bertujuan agar terjadi interaksi antar peserta didik dalam kelompok. (3) Jembatan; kegiatan ini bisa diwujudkan dalam bentuk diskusi kelompok. (4) Tugas; tugas diajukan kepada peserta didik memberikan bantuan agar peserta didik mampu memahami pengetahuan yang akan mereka bangun dari situasi yang telah disajikan. Mempertunjukkan; langkah ini ini melibatkan para peserta didik untuk membuat sesuatu untuk dipresentasika untuk yang lain. (6) Refleksi; refleksi dimaksudkan untuk mengeva-luasi apa yang telah mereka lakukan dan apa yang telah mereka pelajari (Gognan dan Collay, 2006, pp. 4-6).

Dari pendapat-pendapat di atas disimpulkan bahwa model pembelajaran konstruktivisme melalui tahapan berikut: (1) tahap motivasi; peserta didik didorong dan diberi motivasi agar mengemukakan pengetahuan awalnya tentang konsep dari pokok bahasan atau sub pokok bahasan yang akan dibahas; (2) tahap diskusi dan penyelidikan; peserta didik diberi kesempatan untuk menyelidiki dan menemukan konsep-konsep dan permasalahan-permasalahan secara berkelompok; (3) tahap presentasi; peserta didik memberikan penjelasan dan solusi yang didasar-kan pada observasinya ditambah dengan penje-lasan-penjelasan guru; dan (4) tahap aplikasi; peserta didik mengaplikasikan pemahaman kon-sepnya tentang topik pelajaran saat itu dengan bantuan dari guru.

Terkait permasalahan yang telah dikemukakan berikut kajian teorinya, maka peneliti menawarkan solusi untuk mengembangkan perangkat pembelajaran berorientasi konstruktivisme kelas XI TKJ diharapkan dapat membantu guru dalam melaksanakan pembelajaran yang memberikan kesempatan kepada peserta didik untuk mengkonstruksi pengetahuan secara mandiri dan dapat meningkatkan rasa kepercayaan diri peserta didik. Diduga kuat perangkat pembelajaran yang melibatkan peran aktif siswa mampu meningkatkan percaya diri sekaligus prestasi belajar siswa (Hilman \& Retnawati, 2015). Dengan demikian penelitian ini bertujuan untuk menghasilkan perangkat pembelajaran berorientasi konstruktivisme, meliputi Rencana Pelaksanaan Pembelajaran (RPP), Lembar Kegiatan Siswa (LKS), dan Tes Hasil Belajar (THB) mata pelajaran matematika SMK kompetensi keahlian Teknik komputer dan Jaringan (TKJ) yang valid, praktis, dan efektif

\section{METODE}

Jenis penelitian yang dilakukan adalah penelitian dan pengembangan (Research and Development) model 4D, yaitu tahap defining (pendefinisian), tahap designing (perancangan), tahap developing (pengembangan), dan tahap 
disseminating (pendiseminasian). Tahap defining dilakukan untuk melakukan analisis masalah dan solusi, analisis peserta didik, analisis materi, analisis tugas, dan tujuan pembelajaran. Tahap designing dilakukan untuk merandang desain produk yang dihasilkan. Produk yang dikem-bangkan dalam penelitian ini adalah Rencana Pelaksanaan Pembelajaran (RPP), Lembar Kegiatan Siswa (LKS), dan Tes Hasil Belajar (THB) untuk kelas XI SMK kompetensi keahlian Teknik Komputer dan Jaringan (TKJ). Tahap developing meliputi tahap validasi oleh ahli, revisi, dan ujicoba produk. Ujicoba produk dilakukan di SMK Muhammadiyah 2 Yogyakarta secara eksperimen semu dengan desain pretest-posttest nonequivalent comparison-group design. Ujicoba dilakukan pada bulan Mei sampai Juni 2014 dengan kelas XI TKJ 1 sebagai kelas eksperimen dan kelas XI TKJ 2 sebagai kelas kontrol.

Produk akan dinilai dari tiga hal yaitu kevalidan, kepraktisan, dan keefektifan. Instrumen penilaian kevalidan meliputi lembar validasi RPP, lembar validasi LKS, dan lembar validasi THB. Instrumen penilaian kepraktisan meng-gunakan lembar penilaian guru terhadap RPP, LKS, dan THB; lembar penilaian peserta didik terhadap LKS dan THB; dan lembar observasi keterlaksanaan pembelajaran. Instrumen penilai-an keefektifan yang digunakan adalah tes hasil belajar (THB) dan angket kepercayaan diri peserta didik. Lembar validasi dan lembar peni-laian kepraktisan menggunakan rentang skala penilaian 5 yaitu skor 1 , skor 2, skor 3, skor 4, dan skor 5. Data tersebut kemudian dikonversi-kan menjadi data kualitatif dengan menggunakan acuan yang diadaptasi dari Azwar (2010, p.163) sebagai berikut:

Tabel 1. Konversi Data Kuantitatif menjadi Data Kualitatif untuk Kevalidan/Kepraktisan Produk

\begin{tabular}{ll}
\multicolumn{1}{c}{ Interval } & \multicolumn{1}{c}{ Kriteria } \\
\hline $\mathrm{Mi}+1,5 \mathrm{Si}<\mathrm{X}$ & Sangat valid/praktis \\
$\mathrm{Mi}+0,5 \mathrm{Si}<\mathrm{X} \leq \mathrm{Mi}+1,5 \mathrm{Si}$ & Valid/praktis \\
$\mathrm{Mi}-0,5 \mathrm{Si}<\mathrm{X} \leq \mathrm{Mi}+0,5 \mathrm{Si}$ & Cukup valid/praktis \\
$\mathrm{Mi}-1,5 \mathrm{Si}<\mathrm{X} \leq \mathrm{Mi}-0,5 \mathrm{Si}$ & Kurang valid/praktis \\
$\mathrm{X} \leq \mathrm{Mi}-1,5 \mathrm{Si}$ & Tidak valid/praktis \\
\hline Keterangan: & \\
$\mathrm{X}=$ total skor actual & \\
$\mathrm{Mi}=$ rata-rata skor ideal $=\frac{1}{2}$ (skor maksimum + \\
skor minimum)
\end{tabular}

$\mathrm{Si}=$ simpangan baku ideal $=\frac{1}{6}$ (skor maksimum - skor minimum)

Masing-masing perangkat pembelajaran dikatakan valid jika memenuhi kriteria: skor untuk validasi RPP lebih dari 106,67; skor untuk validasi LKS lebih dari 86,67; skor untuk validasi THB lebih dari 26,67. Perangkat pembelajaran matematika yang dikembangkan dikatakan prak-tis jika skor penilaian RPP lebih dari 106,67; skor penilaian LKS lebih dari 86,67; skor penilaian THB lebih dari 26,67; skor rata-rata penilaian peserta didik terhadap produk mencapai rata-rata skor lebih dari 43,33; dan rata-rata persentase keterlaksanaan pembelajaran secara keseluruhan minimal 90\%. Data keefektifan diperoleh dari tes hasil belajar dan angket kepercayaan diri kelas eksperimen dibandingkan dengan kelas kontrol. Data masing-masing kelas diuji keefektifannya dengan menggunakan uji one sample t-test. Kemudian dilanjutkan dengan uji perbedaan rata-rata (MANOVA) dan dilanjutkan dengan uji post hoc t-Bonferoni.

\section{HASIL DAN PEMBAHASAN}

Perangkat pembelajaran yang disusun memiliki karakteristik sebagai berikut: (1) perangkat pembelajaran dikembangkan berdasarkan pada tingkatan kognitif untuk peserta didik SMK yaitu berada pada tahap operasional formal, meskipun demikian masih perlu adanya bantuan visualisasi dalam menyajikan masalah. Visuali-sasi diharapkan dapat memudahkan siswa dalam memahami masalah. Hal ini sesuai dengan pendapat Piaget (Slavin, 2006, p.33-39); (2) masalah-masalah yang disajikan disesuaikan dengan masalah-masalah yang dihadapi peserta didik SMK dengan Kompetensi Keahlian Teknik Komputer dan Jaringan (Permendikbud No. 64 Tahun 2013); (3) adanya pemberian scaffolding pada perangkat yang dikembangkan untuk peserta didik (Vygotsky, 1986, p.xxxv); (4) kegiatan pembelajaran yang dirancang dalam RPP dan aktivitas peserta didik yang dirancang dalam LKS disesuaikan dengan prinsip pembelajaran konstruktivisme dan kurikulum 2013; dan (5) THB dikembangkan berbentuk soal essay karena alur berpikir pemecahan masalah yang mereka pilih akan terlihat dalam proses penye-lesaiannya. Hal ini akan membedakan pema-haman peserta didik terhadap materi. (Miller, Linn \& Gronlund 2009, pp. 140-142).

\section{Data Kevalidan}


Validasi dilakukan untuk menilai kevalidan produk yang dihasilkan. Produk yang dikembangkan divalidasi oleh ahli yaitu dosen pendidikan matematika UNY. Berikut hasil validasi produk tersaji pada tabel berikut.

Tabel 2. Skor Hasil Validasi Perangkat Pembelajaran

\begin{tabular}{cccc}
\hline \multirow{2}{*}{ Validator } & \multicolumn{3}{c}{ Skor Produk yang Divalidasi } \\
\cline { 2 - 4 } & RPP & LKS & THB \\
1 & 150 & 119 & 38 \\
2 & 136 & 108 & 34 \\
Skor Total & 286 & 227 & 72 \\
Rata-rata & 143 & 113,5 & 36 \\
\multirow{2}{*}{ Kriteria } & Sangat & Sangat & Sangat \\
& valid & valid & valid \\
\hline
\end{tabular}

Selain memberikan penilaian terhadap produk berupa perangkat pembelajaran, validator juga memberikan masukan sebagai bahan perbaikan.

\section{Data Kepraktisan}

Setelah divalidasi kemudian produk direvisi. Langkah selanjutnya adalah melakukan ujicoba untuk menilai kepraktisan dan keefektifannya. Data kepraktisan diperoleh dari penilaian guru terhadap RPP, LKS, dan THB. Data yang diperoleh disajikan pada table berikut:

Tabel 3. Skor Hasil Penilaian Guru terhadap Perangkat Pembelajaran

\begin{tabular}{ccc}
\hline Perangkat & $\begin{array}{c}\text { Penilaian } \\
\text { Guru }\end{array}$ & Kriteria \\
\hline RPP & 140 & Sangat baik \\
LKS & 108 & Sangat baik \\
THB & 36 & Sangat baik \\
\hline
\end{tabular}

Berikut hasil penilaian peserta didik terhadap penggunaan LKS dalam pembelajaran dan penggunaan THB sebagai instrumen evaluasi:

Tabel 4. Skor Hasil Tanggapan Peserta Didik terhadap Perangkat Pembelajaran

\begin{tabular}{ccc}
\hline Perangkat & Penilaian & Kriteria \\
\hline LKS dan THB & 46,64 & Baik \\
LKS & 26,11 & Baik \\
THB & 20,54 & Baik \\
\hline
\end{tabular}

Data hasil observasi keterlaksanaan pembelajaran berorientasi konstruktivisme sebagai berikut:

Tabel 5. Persentase Keterlaksanaan Pembelajaran

\begin{tabular}{ccc}
\hline $\begin{array}{c}\text { Pertemuan } \\
\text { ke- }\end{array}$ & $\begin{array}{c}\text { Persentase } \\
\text { Keterlaksanaan }\end{array}$ & Rata-Rata \\
\hline
\end{tabular}

\begin{tabular}{ccc}
\hline \multicolumn{3}{c}{ Pembelajaran } \\
\hline 2 & $81,25 \%$ & \\
3 & $93,75 \%$ & $92,19 \%$ \\
4 & $100 \%$ & \\
5 & $93,75 \%$ & \\
\hline
\end{tabular}

\section{Data Keefektifan}

Data hasil belajar siswa yang dideskripsikan dalam penelitian ini terdiri atas data pretest dan posttest. Secara ringkas, deskripsi data hasil belajar siswa, baik untuk kelas eksperimen maupun untuk kelas kontrol disajikan dalam Tabel 6.
Tabel 6. Deskripsi Data Hasil Belajar

\begin{tabular}{lcccc}
\hline \multirow{2}{*}{ Deskripsi } & \multicolumn{2}{c}{ Kelas } & \multicolumn{2}{c}{ Kelas Kontrol } \\
& Eksperimen & & \\
\cline { 2 - 5 } & Pretest & Posttest & Pretest & Posttest \\
\hline Rata-rata & 21,86 & 81,71 & 24,71 & 77,71 \\
Nilai Maks. & 100 & 100 & 100 & 100 \\
Teoretik & & & & \\
Nilai Min. & 0 & 0 & 0 & 0 \\
Teoretik & & & & \\
Nilai Maks. & 42 & 86 & 36 & 82 \\
Nilai Min. & 8 & 78 & 8 & 74 \\
Standar Dev. & 9,17 & 2,48 & 7,32 & 1,70 \\
Variansi & 84,13 & 6,14 & 53,69 & 2,88 \\
\hline
\end{tabular}

Berdasarkan Tabel 6 di atas, diperoleh informasi bahwa nilai rata-rata hasil belajar siswa, baik untuk kelas eksperimen maupun kelas kontrol sebelum diberikan perlakuan belum mencapai nilai rata-rata 75 dan setelah diberikan perlakuan memiliki nilai rata-rata di atas 75 , yaitu sebesar 81,71 untuk kelas eksperimen dan 77,71 untuk kelas kontrol.

Data kepercayaan diri peserta didik yang dideskripsikan dalam penelitian ini terdiri atas data pretest dan posttest. Secara ringkas, deskripsi data kepercayaan diri peserta didik, baik untuk kelas eksperimen maupun untuk kelas kontrol disajikan dalam Tabel 7 berikut:

Tabel 7. Deskripsi Data Kepercayaan Diri Peserta Didik

\begin{tabular}{lcccc}
\hline \multirow{2}{*}{ Deskripsi } & \multicolumn{2}{c}{ Kelas } & \multicolumn{2}{c}{ Kelas Kontrol } \\
& \multicolumn{2}{c}{ Eksperimen } & & \\
\cline { 2 - 5 } & Pretest & Posttest & Pretest & Posttest \\
\hline Rata-rata & 79,78 & 90,93 & 79,96 & 87,07 \\
Nilai Maks. & 120 & 120 & 120 & 120
\end{tabular}


Teo.

Nilai Min.

Teo.

Nilai Maks.

Nilai Min.

Standar Dev.

Variansi

$$
24
$$

$$
24
$$

$$
103
$$

$$
105
$$$$
103
$$

83

5,30 74,99

$$
62
$$$$
7,23
$$
81 52,26 105 31,25

Berdasarkan Tabel 7 di atas, diperoleh informasi bahwa tingkat kepercayaan diri peserta didik, baik untuk kelas eksperimen maupun untuk kelas kontrol sebelum diberikan perlakuan belum mencapai kategori baik (skor lebih dari 80) dan setelah diberikan perlakuan memiliki skor rata-rata dalam kategori baik, yaitu sebesar 90,93 untuk kelas eksperimen dan 87,07 untuk kelas kontrol.

Uji keefektifan perangkat pembelajaran dilakukan dengan menggunakan uji one sample t-test. Hasil uji dapat dilihat pada table berikut:

Tabel 8. Hasil Uji One Sample t-test Kelas Eksperimen (dengan Perangkat Pembelajaran Berorientasi Konstruktivisme)

\begin{tabular}{ccc}
\hline Aspek & $\boldsymbol{t}$ & Sig. \\
\hline Hasil belajar & 14,362 & 0,000 \\
Kepercayaan Diri & 10,915 & 0,000 \\
\hline
\end{tabular}

Berdasarkan Tabel 8 di atas, diperoleh informasi bahwa nilai signifikansi $t$ untuk semua aspek lebih kecil dari 0,05. Artinya, $\mathrm{H}_{\mathrm{o}}$ ditolak. Atau dengan kata lain, perangkat pembelajaran konstruktivisme efektif ditinjau dari aspek hasil belajar dan kepercayaan diri peserta didik. Hasil untuk kelas kontrol juga menunjukkan bahwa perangkat pembelajaran efektif ditinjau dari hasil belajar dan kepercayaan diri peserta didik.

Selanjutnya dilakukan pengujian perbedaa keefektifan perangkat pembelajaran. Setelah dilakukan perhitungan dengan menggunakan SPSS 16 diperoleh hasil seperti pada Tabel 9.

Tabel 9. Hasil MANOVA Data Setelah Perlakuan

\begin{tabular}{ccc}
\hline & $\boldsymbol{F}$ & Sig. \\
\hline $\begin{array}{c}\text { Kelas } \\
\text { (Setelah Perlakuan) }\end{array}$ & 30,946 & 0,000 \\
\hline
\end{tabular}

Berdasarkan Tabel 9 di atas, diperoleh informasi bahwa nilai signifikansi $F$ lebih besar dari 0,05 untuk data setelah perlakuan. Artinya, kedua kelas tersebut memiliki perbedaan keefektifan untuk kedua aspek yang diukur. Atau dengan kata lain, terdapat perbedaan keefektifan perangkat pembelajaran (berorientasi konstruktivisme dan konvensional) ditinjau dari aspek hasil belajar dan kepercayaan diri.
Setelah diketahui bahwa terdapat perbedaan keefektifan antara kedua perangkat pembelajaran tersebut, maka dilakukan uji lanjut mengenai perangkat pembelajaran mana yang lebih efektif ditinjau dari aspek hasil belajar dan kepercayaan diri. Setelah dilakukan perhitungan dengan menggunakan program Microsoft office excel diperoleh nilai $t$-Benferroni seperti pada Tabel 10 berikut:

Tabel 10. Hasil Uji $t$-Benferroni

\begin{tabular}{ccc}
\hline Aspek & $\boldsymbol{t}$-Benferroni & $\boldsymbol{t}_{\text {tabel }}$ \\
\hline Hasil belajar & 7,049 & 2,0049 \\
Kepercayaan Diri & 2,650 & 2,0049 \\
\hline
\end{tabular}

Berdasarkan Tabel 10 di atas, diperoleh informasi bahwa nilai $t$-Bonferoni lebih dari nilai $\mathrm{t}$ tabel, yang berarti perangkat pembelajaran berorientasi konstruktivisme lebih efektif daripada perangkat pembelajaran konvensional ditinjau dari aspek hasil belajar dan kepercayaan diri peserta didik.

Dari hasil uji di atas, dapat diketahui bahwa dengan menggunakan produk perangkat pembelajaran ini dapat meningkatkan hasil belajar peserta didik. Hal ini sejalan dengan hasil penelitian Hilman \& Retnawati (2015). Hal ini dapat diketahui dari peningkatan rata-rata hasil pretest dan posttest dari 21,86 menjadi 81,71 . Sejalan dengan hal itu, kepercayaan diri juga mengalami peningkatan dari 79,78 menjadi 90,93. Secara lebih jelas disajikan pada gambar berikut:

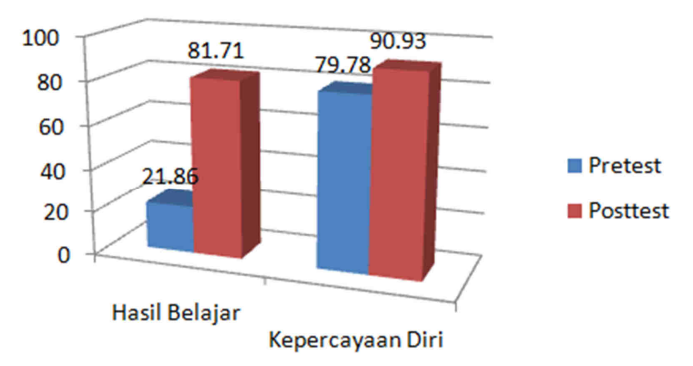

Gambar 1. Grafik Peningkatan Rata-Rata Hasil Belajar dan Skor Kepercayaan Diri Peserta Didik

Dengan demikian penggunaan perangkat pembelajaran konstruktivisme yang melibatkan peran aktif siswa selama proses pembelajaran berlangsung dapat meningkatkan prestasi dan rasa percaya diri siswa. Hal ini sejalan dengan pendapat Hilman \& Retnawati (2015); Mundilarto, (2013); Suhendar \& Widjajanti, (2016). 
Produk ini dapat diaplikasikan untuk peserta didik dengan kemampuan kognitif rendah, sedang maupun tinggi. Produk ini dikhususkan untuk peserta didik pada SMK dengan kompetensi keahlian Teknik Komputer dan Jaringan karena permasalahan yang disajikan merupakan permasalahan yang berkaitan dengan Komputer dan Jaringan. Jika diterapkan pada peserta didik dengan kompetensi keahlian lain, maka permasalahan yang disajikan sebaiknya dimodifikasi sesuai dengan kompetensi keahlian yang sesuai. Langkah pembelajarannya sesuai dengan yang ada pada perangkat ini. Oleh karena itu, perangkat pembelajaran ini sangat sesuai digunakan dalam proses pembelajaran untuk meningkatkan hasil belajar dan kepercayaan peserta didik.

\section{SIMPULAN}

Secara keseluruhan produk yang dikembangkan memenuhi kriteria valid, praktis, dan efektif ditinjaud dari hasil belajar dan kepercayaan diri peserta didik. Berdasarkan hasil dan temuan penelitian, saran yang dapat disampaikan adalah sebagai berikut: (1) guru sebaiknya mengembangkan perangkat pembelajaran sesuai yang dikembangkan peniliti karena perangkat pembelajaran ini mempunyai beberapa keunikan yaitu langkah-langkah pembelajaran konstruktivisme dapat memberikan keleluasaan kepada peserta didik agar mengkonstruksi penge-tahuannya secara mandiri. Selain itu, masalah-masalah yang disajikan merupakan masalah yang berkaitan dengan kompetensi produktif sesuai dengan kompetensi keahlian Teknik Komputer dan Jaringan. (2) guru perlu menelaah dan mempersiapkan sumber belajar dan permasalahan yang akan disajikan, sebelum memulai pembelajaran di kelas sesuai dengan komptenesi keahliannya. (3) produk perangkat pembelajaran yang dihasikan dapat dijadikan sebagai referensi dan bahan masukan para guru dalam menyusun perangkat pembelajaran matematika yang menekankan pada peran aktif peserta didik dan penemuan konsep secara mandiri oleh peserta didik.

\section{DAFTAR PUSTAKA}

Brown, P. L., \& Abell, S. K. (2007). Examining the learning cycle. Science and Children. 3 (1), 58-59.
Clements, D. H., \& Battista, M. T. (2009). Constructivist learning and teaching. Article. [Versi Elektronik]. Diambil pada tanggal 15 Januari 2014 dari www.nctm.org

Dehyadegary, E., et. al. (2012). Academic engagement as a mediator in relationship between emotional intelligence and academic achievement among adolescents in Kerman-Iran. Journal of American Science. 8(9): 823832.

Gagnon, G. W. \& Collay, M. (2006). Constructivst key questions for learning teaching to standards design. London: Corwin Press.

Ghufron, N. \& Rini R.S. (2012). Teori-teori psikologi. Yogyakarta: Ar-Ruzz Media.

Hannula,M. S., Maijala, H., \& Pehkonen, E. (2004). Development Of understanding and self-confidence in mathematics; Grades 5-8. Proceedings of the 28th Conference of the International Group for the Psychology of Mathematics Education, Vol 3, 17-24.

Harjanto. (2003). Perencanaan pengajaran. Jakarta: Rineka Cipta.

Hilman, H., \& Retnawati, H. (2015a). Pengembangan perangkat pembelajaran matematika SMP dengan metode inkuiri pada persamaan dan pertidaksamaan linear satu variabel. Jurnal Riset Pendidikan Matematika, 2(1), 40. https://doi.org/10.21831/jrpm.v2i1.7149

Jacobsen, D., Eggen, P., \& Kauchak, D. (1989). Methods for teaching a skills approach $\left(\begin{array}{ll}3^{\text {rd }} & e d\end{array}\right)$. Columbus-Toronto-LondonMelbourne: Merril Publishing Company.

Kemdikbud. (2013). Peraturan Menteri Pendidikan dan Kebudayaan No. 54 tahun 2013 tentang Standar Kompetensi Lulusan Pendidikan Dasar dan Menengah.

Kemdikbud. (2013). Peraturan Menteri Pendidikan dan Kebudayaan No. 65 tahun 2013 tentang Standar Proses.

Lie, A. (2003). 101 Cara menumbuhkan percaya diri anak. Jakarta: PT Elex Media Komputindo. 
Lindenfield , G. (1997). Mendidik anak agar percaya diri. (Terjemahan Ediati Kamil). London: Harper Collins Publisher. (Buku asli diterbitkan tahun 1994)

Lovat, T., et. al. (2011). Values pedagogy and student achievement. London: Springer.

Margono, G. (2005). Pengembangan instrumen pengukur rasa percaya diri mahasiswa terhadap matematika. Jurnal Ilmu Pendidikan, 12.1, 45-61.

Matthews, M. R. (1998). Constructivism in science education : a philosophical examination. New South Wales: Kluwer Academic Publishers.

Mundilarto, M. (2013). Keefektifan Pendekatan Inquiry Based Learning untuk Meningkatan Karakter Peserta Didik SMA pada Pembelajaran Fisika. Jurnal Pendidikan Matematika Dan Sains, l(1), 24-29. https://doi.org/10.21831/JPMS.V1I1.12 474

Nunes, et. al. (2009). Development of maths capabilities and confidence in primary school. Research Report DCSF-RR118. Oxford United Kingdom: University of Oxford.

Orlich, D. C., et. al. (2007). Teaching strategies a guide to effective instruction. New York: Houghton Mifflin Company.

Piaget, J. (1971). Genetic epistemology. New York: Norton Library.

Preston, L. D. (2007). 365 Steps to selfconfidence. Oxford United Kingdom: How To Books, Ltd.

Slavin, R. E. (2006). Educational psychology theory and practice $\left(8^{\text {th }} e d.\right)$. Boston, MA: Pearson Education Inc.
Stringer, E. T., Christensen, L. M., \& Baldwin, S. C. (2010). Integrating teaching, learning, and action research enhancing instruction in the k-12 classroom. Los Angeles, CA: SAGE.

Suhendar, U., \& Widjajanti, D. B. (2016). Komparasi Keefektifan Saintifik dan PMRI Ditinjau dari Prestasi, Minat, The Comparison of the Effectiveness of Scientific and PMRI Approaches Based on the Achievement, Interest, and SelfConfidence of Students of Grade VII. PYTHAGORAS: Jurnal Pendidikan Matematika, 11(1), 91-101. https://doi.org/http://dx.doi.org/10.2183 1/pg.v11i1.9674

Vygotsky, L. S. (1986). Though and language. Baskerville United States of America: Library of Congress Cataloging in Publication Data

Yates, S.M. (2002). The Influence of Optimism and Pessimism on Student Achievement in Mathematics. Mathematics Education Research Journal, 14 (1), 4-15.

\section{PROFIL SINGKAT}

Dwi Astuti, M.Pd. lahir pada tanggal 23 Oktober 1987 di Bantul, Daerah Istimewa Yogyakarta. Lulus S1 Pendidikan Matematika pada tahun 2010 dan S2 Pendidikan Matematika pada tahun 2014 di Universitas Negeri Yogyakarta. Alamat tempat tinggal di Samiran RT 01, Kelurahan Parangtritis, Kecamatan Kretek, Kabupaten Bantul, Daerah Istimewa Yogyakarta. Nomor HP dan alamat email yang bisa dihubungi: 081328501830 dan dwi.astuti.06@gmail.com. 